\title{
ANALISIS STRUKTUR VISUAL LAMBANG KOTAPRAJA JAMAN HINDIA BELANDA DARI PERSPEKTIF WACANA POSKOLONIAL
}

\author{
Novian Denny Nugraha', Sonson Nurusholih ${ }^{2}$ \\ Desain Komunikasi Visual, Telkom University \\ Jl. Telekomunikasi No. 1, Dayeuh Kolot, Jawa Barat \\ Email : dennynugraha@telkomuniveristy.ac.id
}

\begin{abstract}
The simbol of municipality (big city) in Indonesia is changing from time to time, as well as changing according to the social and cultural conditions of the city. If in colonial era the simbol of the city is a representation of the power of the government or rule, and then the phenomenon is now beginning to change in the current era, where the simbol of the city functioned also for the needs of tourism. In the late Dutch East Indies colonial era around 1930s, some cities were considered to be self-reliant by government and economy, so that the government at that time made a simbol for the need to run the wheels of his government.

The interesting phenomenon of the simbol of the city simbolically is the existence of simbols that are displayed, both simbols affiliated to the ruler (Dutch East Indies) and also the simbol that is a typical simbol of the city's local tradition. Composition and relationship between simbols in the city simbol is interesting to be studied and analyzed. Especially at visual structure area and meaning representation. The analysis is done by qualitative research method which is descriptive interpretative with semiotics theory approach for sign analysis and using postcolonial theory for understanding the meaning of the city simbol.

The results of the analysis both in the visual structure and in the meaning shows the existence of different types of simbols that appear, as well as the discovery of the difference of simbol dominance in each simbol of the city. The relation between the simbols generated from the composition of the visual structure results in a new understanding, which in the postcolonial perspective will be interpreted by a binary opposition relationship, or the dominant/hegemonic relationship between the colonial government and the colony state, between "The Other" and "The Occident", or between colonizing and colonized countries. Furthermore, the simbolic relation on the visual structure and meaning resulted in the ideological significance of the sociocultural conditions of the community at that time.
\end{abstract}

Keywords: Simbol of Municipality, Visual structure, Postcolonial. 


\section{PENDAHULUAN}

Setiap daerah (kota, kabupaten atau provinsi) di Indonesia mempunyai lambang daerah. Lambang daerah tersebut pada umumnya menggambarkan kondisi lingkungan, sejarah, karakteristik atau citacita yang ingin dicapai. Dari sekian banyak daerah di Indonesia, ada beberapa kota yang memakai lambang yang cukup lama bertahan sejak jaman kolonial seperti lambang kota praja Makassar, Medan, Padang, Bandung, Malang, Pasuruan, Blitar, Salatiga, Surabaya, Semarang, Ambon, Manado, Palembang, Cirebon, Magelang dan Madiun, dengan beberapa perubahan atau masih bertahan dengan lambang lamanya. Daerah yang sudah mempunyai lambang seperti ini, umumnya adalah daerah yang saat zaman Hindia Belanda (Dutch East Indies) sudah menjadi kotapraja (gementee). Lambang yang sama atau dengan sedikit perubahan atau masih mempunyai kemiripan ini, tetap dipertahankan, karena kemungkinan memang nilai-nilai yang terdapat dalam lambang tersebut masih sesuai dengan nilai atau potensi dari daerah tersebut. Keberadaan lambang bagi pemerintah daerah tidak sekadar memiliki fungsi sebagai identitas daerah, melainkan juga menunjukkan adanya kesadaran daerah atau nilai-nilai dan potensi sosio-kultural yang dimiliki oleh daerah tersebut.

Sumber utama rujukan dari objek penelitian ini adalah data visual yang di dapat dari buku Geilustreerde Encyclopaedia van Nederland Indie, karangan G.F.E Gonggryp. Diterbitkan di Leiden oleh $N V$ Leidsche Uitgeversmaatschappij 1934, yang kemudian diterbitkan oleh penerbit KPG (Kompas Popular Gramedia), yang disadur penulis F. Swantoro terbit pertama tahun 2002 dan di cetak ulang tahun 2006.
Dalam buku tersebut terlihat lambanglambang pemerintah kotapraja di Indonesia dekade tahun 1930-an, dimana jika dilihat dari ragam simbol visual yang tampak pada lambang daerah memperlihatkan semangat jaman (zeitgeist) pada era tersebut, yang pada umumnya terbentuk dari model bentuk dasar yang mengadopsi lambang visual pemerintahan Kerajaan Hindia Belanda atau kerajaan di Eropa pada umumnya yang menggunakan bentuk tameng atau perisai. Simbol lain yang ada pada lambang tersebut mengangkat mengenai simbol-simbol lokal yang merupakan identitas khas daerah atau sumber daya wilayah tersebut. Oleh karena itu interelasi antar lambang didalamnya yaitu simbol khas Kerajaaan Hindia Belanda dan simbol identitas lokal, menjadi fenomena yang menarik untuk dikaji.

Berangkat dari fenomena tersebut, maka dilakukan penelitian berbentuk analisis mengenai struktur visual lambang Kotapraja jaman Hindia Belanda era tahun 1930-an tersebut. Analisis dilakukan selain pada ranah struktur visual dalam hal ini juga menelaah interelasi antar simbol pada lambang tersebut, juga yang lebih penting adalah analisis terhadap makna yang timbul dari keberadaan simbol visual pada lambang tersebut. Tafsiran makna yang muncul dari lambang tersebut akan ditafsirkan melalui pendekatan atau perspektif teori poskolonial (setelah kemerdekaan) sebagai sebuah pendekatan makna atas lambang tersebut. Sehingga penelitian ini selain akan menafsirkan struktur bentuk, relasi antar simbol yang ada dalam lambang tersebut, juga akan menafsirkan maknanya dari persfektif teori poskolonial. Sementara struktur bentuk lambang akan dianalisis dengan teori semiotika, mengingat diperlukannya pemahaman akan tanda yang digunakan dalam lambang dan kaitannya dengan kondisi realistis wilayahnya. 


\section{TINJAUAN TEORITIK}

Mengkaji pemaknaan visual merupakan kajian yang tidak hanya membahas secara kontekstual saja, melainkan mendefinisikan sebuah pemaknaan yang terlihat maupun tidak terlihat. Dengan semiotika hal ini mampu menggali hal-hal yang bersifat subtansial dari penggunaan bahasa maupun visual tentang seperangkat nilai atau bahkan ideologi yang tersembunyi. Metode semiotika ini bersifat kualitatifinterpretatif, yaitu sebuah metode yang memfokuskan pada tanda dan teks sebagai objek kajiannya serta bagaimana peneliti menafsirkan dan memahami kode dibalik tanda dan teks tersebut. Nilai-nilai sosial yang terdapat dalam masyarakat ini mendorong tim peneliti untuk menggunakan kajian semiotika dari Roland Barthes untuk teknis membaca dan menganalisa lambang kotapraja Indonesia jaman kolonial tersebut.

Penelitian dengan teori semiotika Roland Barthes, menjelaskan bahwa terdapat makna denotatif sebagai sistem tanda pada tataran pertama, konotatif sebagai sistem tanda tataran kedua dan mitos atau ideologi yang berfungsi untuk mengungkapkan serta memberikan pembenaran bagi nilai-nilai dominan yang berlaku dalam periode atau masa-masa tertentu. Dalam mitos atau ideologi sendiri terbagi menjadi 3 dimensi, yaitu penanda (signifier), petanda (signfied) dan tanda (sign). (Barthes dalam Hoed, 2007: 300).

Teori poskolonial dalam penelitian ini digunakan sebagai perspektif dalam menganalisi makna yang dimunculkan dari lambang yang di analisis. Teori poskolonial muncul sebagai sebuah "perlawanan" atau oposisi dari teori kolonial, dikenal pula sebagai oposisi biner dari kolonial atau oksidental. Oksidentalisme (barat) sebagai ikon negara kolonial (penjajah), sedangkan oriental atau timur sebagai Negara-negara yang dijajah (discolonisasi). Analisis wacana poskolonialis pada umumnya digunakan di satu pihak untuk menelusuri aspek-aspek yang tersembunyi atau sengaja disembunyikan sehingga dapat diketahui bagaimana kekuasaan itu bekerja, di pihak lain membongkar disiplin, lembaga dan ideologi yang mendasarinya.

Ada tiga tokoh dalam teori wacana poskolonial yang dikenal yaitu Edward W. Said, Gayatri C. Spivak, dan Homi K. Bhabha. Apabila Edward W. Said menyoroti permasalahan dominasi dan manipulasi Barat terhadap ilmu pengetahuan dan ideologi yang dipergunakan sebagai alat untuk terus menjajah. Said juga menyoroti masalah ideologi, dimana kolonialisme menciptakan steriotip-steriotip dan ideologi tentang "the orient" yang diidentikkan dengan "The Other" atau yang lain "The Occident" (the self). Pandangan ini telah dikontruksi oleh sarjana-sarjana barat berbagai generasi sehingga terjadi steriotip misalnya kemalasan, kecurangan, ketidakmampuan berpikir rasional, adalah milik orang-orang timur (negeri jajahan). Sementara itu Spivak selalu berbicara tentang kelompok-kelompok masyarakat yang terpinggirkan, kaum marginal yang tidak jarang terlupakan bahkan sengaja dilupakan. Spivak menyebutnya dengan istilah subaltern. Baginya, subaltern adalah kelompok marginal yang selalu menjadi objek dari kelas dominan dan berkuasa (baik dari kelompok dalam maupun kelompok luar), sedangkan Homi K. Bhabha menyoroti tentang "ruang ketiga" atau "ruang antara" yang terbentuk sebagai hasil negosiasi antara budaya penjajah dengan budaya yang terjajah. Di dalam "ruang ketiga" inilah, Bhabha, menjelaskan tentang persoalan identitas ganda yang dilahirkan sebagai 
akibat dari kontruksi subjek antara yang menjajah dengan yang dijajah atau sebaliknya.

Dalam wacana penelitian ini lewat simbol-simbol yang dimunculkan pada lambang-lambang kotapraja jaman Hindia Belanda, akan ditemukan bagaimana kekuasaan dan ideologi itu bekerja. Belanda yang pada waktu itu sebagai penjajah merepresentasikan tingkat kekuasaan dan ideologinya dalam lambang tersebut sesuai dengan lokasi dimana lambang itu berada. Lambang Kotapraja yang menjadi objek penelitian ini dianalisis hanya untuk melihat dan membaca sejauh mana negara kolonial menerapkan dan mempersiapkan sistem tandanya, pada saat proses penjajahan itu berlangsung melalui analisis struktur tandanya. Analisis tidak mengarah ke kajian histori, karena sulitnya penelusuran data dan akses untuk itu, tetapi sebagai contoh lambang kotapraja Semarang secara histori erat kaitanya dengan perang Dipenogoro 1825-1830, tentunya demikian juga dengan lambang lainnya.

\section{ANALISIS STRUKTUR VISUAL LAMBANG KOTAPRAJA ZAMAN HINDIA BELANDA}

Struktur visual yang dimaksud pada analisis ini adalah kondisi fisik (teks) dari lambang kotapraja tersebut yang terdiri dari semua komposisi dan elemen visual, seperti jenis simbol/gambar, penempatan posisi simbol, relasi antar simbol dan elemen visual lain khususnya warna. Mekanisme analisis dibagi menjadi beberapa tahapan sebagai berikut:

1. Analisis kategorisasi pada lambang sejenis; kategorisasi ini diperlukan untuk menemukan jenis simbol apa saja yang bisa dikategorisasikan sama, sehingga didapat kota mana saja yang masuk kategori ini.

2. Analisis Semiotik, Setiap kategori dianalisis struktur visualnya. Pada analisis ini penekanan akan terlihat pada temuan makna denotatif dan konotatif dan makna ideologis yang muncul akibat dari struktur visual yang ada tersebut.

3. Analisis makna, pada analisis ini dilakukan pendekatan dengan wacana teori poskolonial dimana pembahasan lebih menekankan pada interelasi makna dalam lambang tersebut, khususnya hubungan oposisi biner antara makna lambang yang berafiliasi ke penguasa / penjajah dalam hal ini pemerintah Hindia Belanda dan di satu sisi adalah makna lambang yang berafiliasi kepada lambang dan identitas budaya lokal sebagai negeri yang terjajah.

Berikut adalah visual lambang kota yang diberikan otonomi (kotapraja/gemente) oleh pemerintah Hindia Belanda dan yang digunakan dalam kegiatan pemerintahan dalam kurun waktu tahun 1905-1942 yaitu:
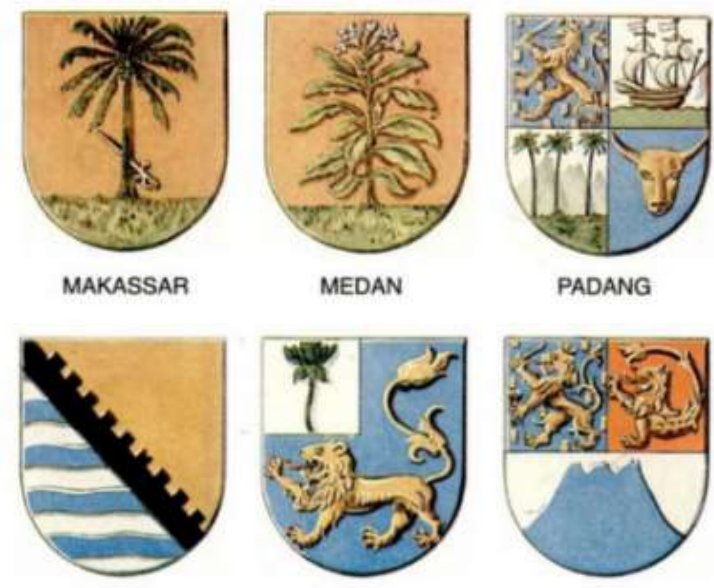

BANDOENG

MALANG
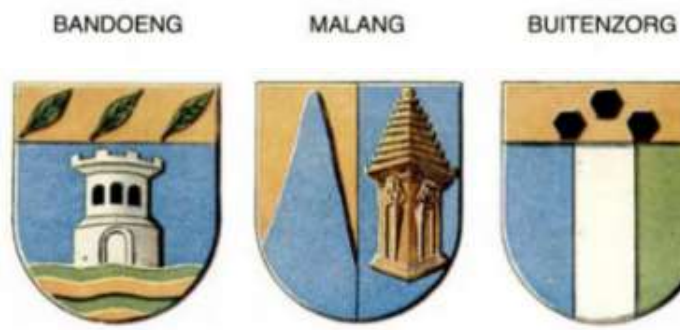

PASOEAOEAN

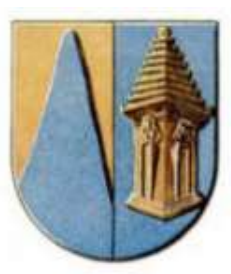

BLITAA

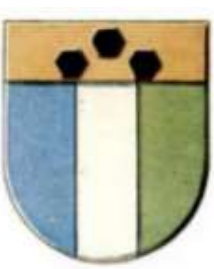

SALATIGA 


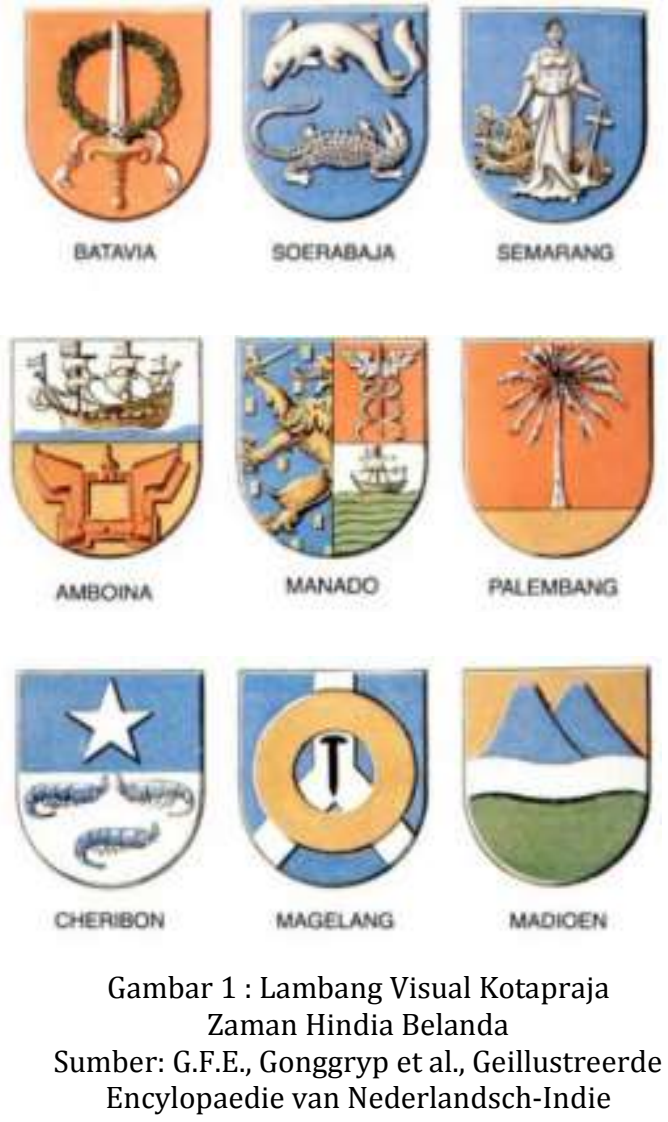

III.1 ANALISIS KATEGORI SIMBOL

Dari objek penelitian diatas maka secara struktur visual dapat dikategorikan jenis jenis lambang kotapraja pada 5 kategori sebagai berikut:

1. Lambang dengan menampilkan simbol aset "komoditas" daerah, terdiri dari kotapraja Makassar bersimbol kelapa/sawit dan pedang, Medan bersimbol tembakau, Palembang bersimbol kelapa/sawit.

2. Lambang dengan menampilkan simbol identitas lokal, non komoditas tapi aset budaya seperti terlihat pada: Cirebon bersimbol udang, Pasoeroean bersimbol menara air dan daun tembakau, Blitar bersimbol candi dan Surabaya bersimbol hiu dan buaya.

3. Lambang dengan kombinasi simbol identitas lokal dan identitas Kerajaan Hindia Belanda terlihat pada: Padang bersimbol kepala kerbau dan pohon kelapa (simbol lokal Padang) dan singa dan kapal dagang sebagai simbol kerajaan dan perdagangan kerajaan Hindia Belanda, kotapraja Malang berlambang singa (kerajaan Hindia Belanda) dan bunga teratai (simbol lokal Malang), kotapraja Buitenzorg/Bogor bersimbol singa dan singa laut sebagai simbol penguasa dan militer Hindia Belanda dan simbol gunung Salak sebagai simbol lokalitas Bogor.

4. Lambang dengan keseluruhan simbol penguasa Hindia Belanda terlihat pada lambang kotapraja Batavia (kini Jakarta), Semarang, Ambonia dan Manado

5. Lambang dengan simbol identitas abtraksi potensi alam terlihat pada lambang kotapraja Bandung, Salatiga, Magelang Madioen dan Magelang.

Dari hasil analisis kategori ini ditemukan bahwa kesemua lambang kotapraja menggunakan simbol pengikat yang sama yaitu simbol tameng dimana simbol ini pada umumnya adalah elemen pada lambang di kerajaaan Eropa yang bergaya Heraldy. Penggunaan tameng disini menguatkan ciri khas kerajaan yang dibangun dengan pondasi kemiliteran.

Hasil analisis juga memperlihatkan bahwa lambang-lambang yang berafiliasi kepada simbol-simbol Hindia Belanda sebagai negeri penjajah bisa dilihat dari simbol singa, singa laut, kapal dagang, pedang, wanita berpedang, dan simbol mitologi eropa lainnya.

Sedangkan lambang identitas lokal akan terlihat simbol-simbol seperti komoditi tanaman perkebunan, potensi kekayaan alam, simbol mitologi lokal dan aset budaya. Diantara keduanya juga terdapat simbolsimbol abstraksi dari potensi alam atau nilainilai tertentu yang berlaku di masyarakat setempat seperti penerapan simbol pada kotapraja Bandung, Salatiga dan Magelang. 
Dari penggayaan simbol ditemukan juga bahwa simbol-simbol yang muncul dari objek penelitian ini bergaya natural realis ilustratif simbolik, heraldic realis ilustratif simbolik dan abstrak metaforis simbolik.

Sedangkan dari eleman visual lain khususnya warna hanya ditemukan warna orange, biru dan hijau dengan dominasi pada warna orange dan hijau yang merupakan warna khas dari kerajaaan Hindia Belanda, wangsa Van Oranje, sedangkan warna hijau umumnya merujuk kepada nilai lokal Nusantara sebagai negeri terjajah dengan kekayaan sumber dayanya.

\section{III.2 ANALISIS STRUKTUR VISUAL DAN MAKNA SIMBOL}

\section{Analisis pada kategori ke satu;}
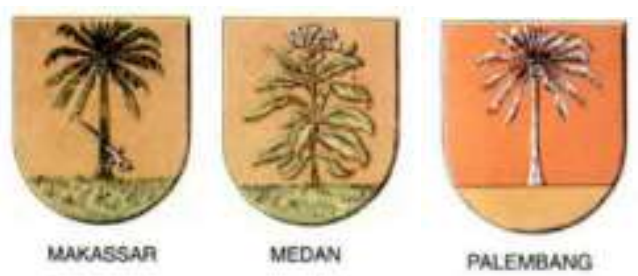

Pada kategori ini simbol simbol denotasi yang muncul adalah potensi "komoditas" dari kotapraja tersebut yaitu Tembakau (Medan) kelapa/sawit (Palembang dan Makassar), warna orange yang mendominasi latar belakang ketiga lambang tersebut, serta simbol pedang yang menusuk pohon kelapa pada lambang kota Makassar.

Makna konotasi yang muncul dari ketiga lambang kotapraja tersebut dapat ditafsirkan bahwa potensi komoditas dari ketiga kotapraja tersebut dikuasai oleh pemerintahan Hindia Belanda yang direpresentasikan dalam warna orange yang sangat dominan sebagai latar belakang. Warna orange dapat dipastikan sebagai warna pemerintahan Hindia Belanda, karena warna tersebut tidak terlalu dikenal dalam tradisi ketiga daerah tersebut yang umumnya di dominsasi oleh warna merah, hitam dan putih seperti halnya pada tradisi gorga di Sumatra Utara (Batak) dan juga pada tradisi di Sulawesi Selatan yang cenderung berwarna merah. Demikian juga pada tradisi Palembang dan melayu pada umumnya yang muncul adalah warna kuning bukan orange.

\section{Kesimpulan atas kategori ini:}

Kesimpulan dari analisis pada kategori ini adalah bidang ruang visual yang menempatkan simbol di dalamnya hanya terdiri dari satu bidang saja pada bentuk tameng, elemen visual yang muncul selain simbol adalah dominasi warna orange. Khusus pada lambang Makasar ada makna konotatif dengan munculnya simbol pedang yang tertancap pada pohon sebagai representasi dari kontrol "militer' pada aset komoditas tersebut.

\section{Analisis pada kategori kedua;}
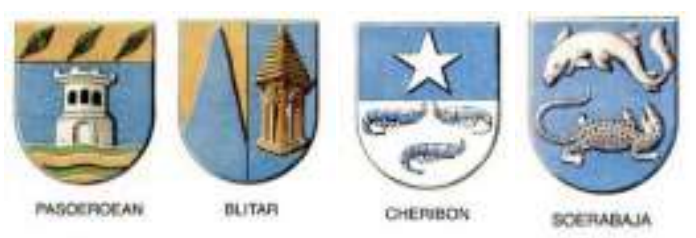

Pada kategori ini menampilkan simbol identitas lokal, non komoditas tapi lebih cenderung menuju ke pemberdayaan aset budaya setempat dan kultur yang berlaku di masyarakat setempat seperti terlihat pada: Pasoeroean, Blitar, Cirebon dan Surabaya.

Pada kategori ini terdapat tanda-tanda denotasi seperti pada kotapraja Pasuruan menampilkan menara air khas Pasuruan buatan pemerintah kolonial yang menjadi ikon dari kota ini dengan latar belakang warna biru serta tiga daun yang berwarna oranye, serta aliran air. 
Pada lambang kota Blitar, struktur visual tameng dibagi menjadi dua bagian yaitu representasi dari bentuk Gunung Kelud serta disampingnya adalah visual dari candi Penataran dengan latar belakang warna orange dan biru.

Sedangkan pada simbol kota Surabaya tampaknya simbol Suro dan Boyo yang sudah menjadi ciri khas budaya diadopsi sebagai representasi makna yang menggambarkan peristiwa heroik yang terjadi di kawasan Ujung Galuh (Surabaya), yaitu kemenangan pasukan Raden Wijaya dengan pasukan TarTar pada tahun 1293. Simbol tersebut digambarkan pertempuran antara buaya (air tawar) dan ikan hiu (laut).

Pada lambang Cirebon terlihat simbol denotasi udang (rebon) dan bintang yang merepresentasi kota Cirebon sebagai kota pelabuhan yang penting dengan bukti beberapa kerajaan Islam di Cirebon serta hasil olahan laut yang menjadi latar kebudayaan masyarakatnya hingga dikenal menjadi beragam produk masa itu.

Makna konotatif yang muncul dari lambang-lambang pada kategori ini adalah tampak ketiga tempat kotapraja terlihat masih memunculkanya warna-warna simbol kolonial secara dominan terutama warna oranye dan biru, walau demikian terlihat penguasa memberikan ruang terhadap simbol-simbol lokal. Terutama terlihat pada kota Surabaya dan juga Blitar, sementara di lambang kota Pasoeroean walaupun menggunakan lambang lokal (menara air) yang sebenarnya adalah bentuk arsitektural buatan penguasa Belanda.

\section{Kesimpulan atas kategori ini:}

Dominasi simbol lokal cukup diberi tempat pada kategori ini, simbol udang di
Cirebon; hiu dan buaya di Surabaya dan kota Blitar tampak simbol lokal sangat kuat terlihat, sedangkan pada Pasuruan walau simbol lokal dimunculkan tetapi tetap menampilkan simbol yang diambil dari artefak yang dibuat penguasa (Menara air). Tanda konotatif pada kelompok ini terlihat adanya upaya memberikan peluang kepada masyarakat lokal tetapi tetap dalam kontrol penguasa (terlihat dari dominasi warna).

\section{Analisis pada kategori ketiga;}
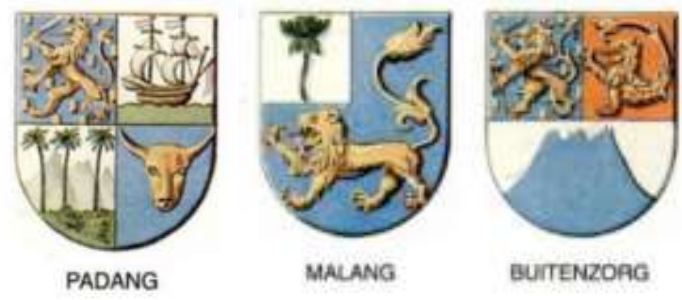

Lambang pada kategori ini berisi struktur kombinasi antara simbol identitas lokal dan identitas kolonial, dan terlihat pada lambang pada kota Padang, Malang, dan Buitenzorg (Bogor).

Tanda denotatif yang muncul terlihat seperti berikut: pada simbol kota Padang bentuk dasar tameng dibagi menjadi empat bagian dua bagian atas adalah simbol penguasa dalam hal ini pemerintah Hindia Belanda dan simbol perdagangan (kapal laut) VOC. Dua bidang dibawah terletak simbol dari kepala kerbau (simbol masyarakat Sumatra Barat) dan pohon kelapa (komoditas). Pada Kota Malang simbol lokal (bunga teratai) ditempatkan seperempat bagian dari keseluruhan bidang dimana 3 bagian nya di dominasi oleh simbol singa sebagai simbol penguasa. Pada kota Bogor bidang perisai dibagi menjadi 3 bagian dimana dua bagian utama di atas adalah simbol penguasa Hindia Belanda terutama simbol pemerintahan (singa) dan simbol militer (singa laut) dengan latar warna biru. 
Makna konotatif yang terlihat dari lambang pada kategori ini adalah walaupun terlihat komposisi yang berimbang atau setidaknya memberi peluang kepada simbol lokal, tetapi terlihat secara struktur visual simbol kolonial menempatkan dirinya sangat dominan baik dengan komposisi menempatkan simbolnya di bagian atas (kota Padang), menempatkan dirinya pada tiga bagian dominan (kota Malang), atau menempatkan simbol pada bagian atas (kota Bogor). Dengan melihat struktur visual seperti ini muncul makna konotatif bahwa ketiga kota ini ada dalam kuasa pemerintahan Hindia Belanda walaupun memberikan tempat untuk masyarakat lokal.

\section{Kesimpulan dari kategori ini:}

Dominasi simbol kolonial pada kategori ini terlihat dari upaya penempatan simbolsimbol tersebut pada posisi yang "mudah terbaca" baik disimpan di bagian atas, atau menguasai seluruh bidang dan menempatkan simbol lokal pada posisi kurang strategis. Walaupun terlihat mencoba memberikan ruang pada simbol lokal sebagai representasi masyarakat lokal, tetapi dominasi kekuasaan tetap terlihat.

\section{Analisis pada kategori ke empat.}
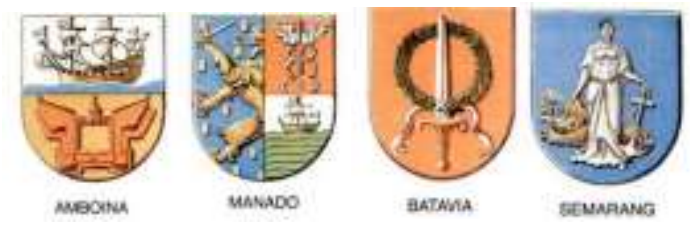

Pada kategori ini tanda denotatif pada struktur visual lambang didominasi oleh simbol kolonial, terlihat pada lambang Batavia, Semarang, Ambonia dan Manado. Dominasi simbol kolonial pada kota ini terlihat sangat menonjol dengan berbagai bentuk simbol yang dihadirkan seperti: singa, kapal dagang, benteng, pedang tongkat mercuri, untaian daun, wanita dengan pedang. Demikian juga dengan warna sangat didominasi oleh warna kolonial khususnya orange. Dan cenderung bergaya Eropa (gaya Heraldry).

Tanda konotatif yang muncul adalah dengan dominasi simbol-simbol kolonial itu, dapat dikatakan bahwa kekuasan kolonial di kota tersebut sudah sangat kuat, dan kota itu sudah menjadi milik kolonial tanpa memberikan peluang kepada masyarakat lokal dengan simbol-simbolnya.

\section{Kesimpulan dari kategori ini:}

Dominasi total simbol kolonial pada lambang kotapraja kategori ini menyiratkan bahwa kekuasaan kolonial sudah kuat tertanam pada kotapraja ini baik pada kekuasan pemerintahan, militer ataupun perdagangan.

\section{Analisis kategori ke lima.}

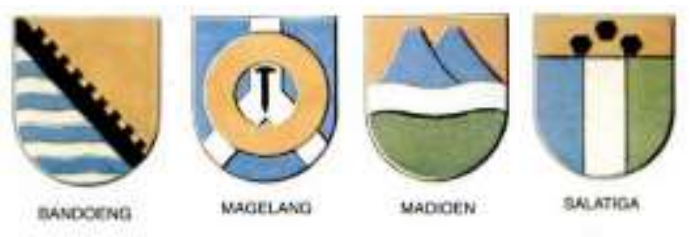

Dalam kategori ini lambang dihadirkan dengan melakukan stilasi atau penyederhanaan atau pembuatan abtraksi potensi alam yang terlihat pada lambang kota Bandung, Salatiga, Magelang dan Madioen .

Tanda denotasi yang muncul pada lambang kotapraja kategori ini didominasi oleh simbol-simbol alam yang lebih abstrak yang meminimalisir adanya simbol-simbol kolonial. Bentuk visual seperti pegunungan, air dan perpaduan bentuk geometri yang beragam seperti persegi dan lingkaran yang membuat lambang kota tampak berbeda. 
Beberapa simbol muncul secara metaforis, misalnya simbol paku di kota Magelang sebagai simbol dari gunung Tidar sebagai "pakunya Pulau Jawa"

Makna konotatif yang dihadirkan, ada dua kemungkinan, yaitu bahwa untuk kotapraja ini sudah tidak harus dikontrol lagi oleh penguasa secara militer, perdagangan atau pemerintahan atau kemungkinan kedua bahwa kondisi kotapraja ini sudah sangat kondusif secara kekuasaan sehingga kemungkinan diberikan kekuasaannya pada kuasa sipil.

\section{Kesimpulan pada kategori ini:}

Tidak terlihatnya tanda denotatif kekuasaan pada lambang kotapraja ini menyiratkan tanda konotasi bahwa kotapraja ini sudah tidak harus di kontrol lagi oleh penguasa secara militer, perdagangan atau pemerintahan atau kemungkinan kedua bahwa kondisi kotapraja ini sudah sangat kondusif secara kekuasaan sehingga kemungkinan diberikan kekuasaannya pada kuasa sipil.

\section{ANALISIS WACANA POSKOLONIAL}

Wacana steriotip ideologi tentang "the orient" yang diidentikkan dengan "the other" atau yang lain, dalam hal ini untuk entitas terjajah dan "The Occident" (the self) sebagai penjajah atau penguasa pada pemahaman Edward W. Said, tampak terlihat pada hampir semua kategori lambang yang dianalisis.

Tampilan struktur visual memperlihat bahwa dengan menggunakan simbol tameng dengan bentuk meruncing di bagian bawah yang notabene lebih cenderung sebagai simbol yang dipakai pada entitas masyarakat Eropa, dan kurang dikenal dalam simbol masyarakat tradisional, primordial atau masyarakat umumnya di Indonesia/ Nusantara, secara konotatif memperlihatkan hegemoni "the occident" terhadap "the other". Simbol-simbol denotatif "the other" dimunculkan di bentuk dasar identitas tameng dengan berbagai posisi penempatan.

Pada struktur lambang ini pun ditemukan juga tingkatan hegemoni pada setiap kategori lambang tersebut. Hegemoni yang dilakukan oleh penguasa terlihat pada tataran politik pemerintahan dan ekonomi juga kekuasaan civil yang ditempatkan secara beragam, pada setiap lambang terkait.

Pada lambang kategori pertama "The Other" ditempatkan secara dominan, walau simbol yang muncul adalah simbol-simbol tentang komoditas perkebunan. Sedangkan hegemoni "The Occident" sangat terlihat pada lambang kategori keempat, Batavia, Semarang, Ambonia, dan Manado. Pada lambang ini tidak terlihat sama sekali simbol yang merepresentasikan "The Others".

Pro-kontra, lawan-kawan, penjajahterjajah, Barat-Timur, Belanda-Nusantara, menciptakan ambivalensi entitas baik pada struktur sosial entitas tersebut juga pada identitas yang terpresentasikan dalam identitas visual pada lambang tersebut. Kondisi demikian menciptakan "hibriditas", dengan berbagai derajat hibriditas pada setiap entitas dari lambang tersebut. Representasi hibriditas yang kuat terlihat pada lambang kategori ketiga, pada lambang kotapraja Padang, Malang, dan Buitenzorg (Bogor), dimana dominasi simbol dengan simbol lainya pada lambang tersebut terlihat seimbang sekaligus memperlihatkan pola hibriditas tersebut. Kemudian Hibriditas itu akan kurang terlihat pada lambang-lambang 
Batavia, Semarang, Ambonia dan Manado pada kategori ke empat, yang muncul adalah hegemoni kekuasaan atas semua elemen sosial masyarakatnya, seperti pada hegemoni kekuasan ekonomi dan politik, pemerintah dan sosial.

Pemakaian elemen simbol-simbol barat dalam lambang kotapraja tersebut yang notabene merupakan lambang-lambang kolonial, apabila dilihat dari kurun waktu sekitar tahun 1920-1930, merupakan sebuah transisi kontruksi sosial dan kebangsaan masyarakat Indonesia dari kontruksi sosial tradisional menuju sebuah negara modern, seperti diketahui pada era itu, merupakan era pergerakan, dimana terjadi resistensi yang luar biasa terhadap dominasi dan hegemoni kolonial yang membentuk entitasentitas pergerakan kebangsaan baik berbentuk organisasi masa, atau organisasi/ partai politik yang umumnya melakukan perlawanan terhadap keberadaan pemerintahan kolonial dalam hal ini adalah pemerintah Hindia Belanda. Keberadaan simbol-simbol kotapraja, yang merupakan simbol dari kota-kota besar yang ada ketika itu. Walau demikian periode ini juga merupakan periode ketika kekuasaan kolonialisasi mencapai puncaknya, dimana sebelumnya kolonialisasi dilakukan oleh kongsi perusahaan dagang (VOC) beralih kepada kerajaan Belanda, yang secara struktur kenegaraan mulai menerapkan sistem pemerintahannya.

\section{KESIMPULAN}

Secara umum pemunculan tanda denotatif dari lambang-lambang yang dianalisis terhadap struktur visualnya tersebut memperlihatkan temuan-temuan yang cukup menarik terutama pada tataran struktur visual , karakteristik dan interelasi antar simbol pada lambang tersebut, dimana hasil temuan ini tentunya bisa dimaknai secara konotatif. Adapun temuan di tataran tanda denotatif adalah:

a. Gaya simbol yang memperlihatkan adanya kemunculan beberapa gaya simbol yaitu Natural Realis Ilustratif Simbolik; Heraldic Realis Ilustratif Simbolik dan Abstrak Metafosis simbolik.

b. Posisi simbol pada lambang terlihat ditempatkan dalam beberapa alternatif latar bidang baik bidang tunggal, bidang dua, bidang tiga dan bidang empat. Besarnya ukuran simbol dan jenis simbol yang ditempatkan pada bidang tersebut secara denotatif memperlihatkan adanya dominasi simbol Hindia Belanda terutama pada bentuk bidang berbentuk tameng yang secara umum dipahami simbol khas bangsa eropa, serata dominasi juga pada warna Orange dan Biru sebagai warna negeri kolonial (Hindia Belanda) dan juga simbol-simbol kekuasaan lain yang merujuk kepada kuasa ekonomi, militer, pemerintahan dan sosial. Besarnya ukuran simbol dalam bidang terlihat beragam yang bisa dimaknai secara konotatif memperlihatkan bagaimana beragamnya dominasi dan kondisi negeri kolonial sesungguhnya kontruksi sosial di setiap kotapraja tersebut, pada saat lambang tersebut masih digunakan.

c. Interelasi antar simbol pada lambang tersebut memperlihatkan adanya dinamika dominasi atau juga kompromi antar lambang khas negara kolonial, dan simbol budaya lokal khas dari lokasi daerah dimana kotapraja tersebut berada. Interelasi antar simbol tersebut tidak terlihat pada lambang kotapraja dimana pusat kekuasan pemerintahan ekonomi dan militer kolonial berada pada kota tersebut seperti Batavia dan Semarang. 
Pada tataran Makna, tanda denotatif dari elemen simbol dan struktur visual yang terkomposisikan pada lambang tersebut memunculkan pemaknaan konotatif terutama memperlihatkan hegemoni "the occident" terhadap "the other". Hegemoni ini terlihat pada hampir semua simbol sebagai representasi struktur sosial pada kotapraja tersebut, seperti simbol tameng dan warna orange dan biru sebagai simbol negeri kolonial, simbol singa dan singa laut sebagai simbol kuasa politik dan pemerintahan, simbol kapal dagang dan benteng sebagai simbol kuasa ekonomi dan perdagangan, dan juga simbol khas negeri eropa lainnya. Kecenderungan hegemoni tersebut tampaknya juga mempunyai gradasi yang berbeda pada beberapa lambang kotapraja lainya dengan menghadirkan simbol-simbol budaya lokal, sehingga terkesan terjadi ambivalensi yang menghasilkan hibriditas simbol. Lambang kotapraja yang digunakan pada kurun waktu sekitar tahun 1920-1930, merupakan sebuah transisi kontruksi sosial dan kebangsaan masyarakat Indonesia dari kontruksi sosial tradisional menuju sebuah negara modern, sekaligus sebuah transisi kesadaran masyarakat negeri kolonial untuk membangun politik etis terhadap negeri koloninya. Seperti diketahui pada era itu, merupakan era pergerakan, dimana terjadi resistensi yang luar biasa terhadap dominasi dan hegemoni kolonial yang membentuk entitas-entitas pergerakan kebangsaan. Sehingga keberadaan lambang kotapraja yang cenderung hibrid ini seolah merupakan upaya kompromi dari resistensi tersebut.

\section{DAFTAR PUSTAKA}

[1] Anna, Lumba. 2016. Kolonial dan Post Kolonial. Jalasutra, Yogyakarta.

[2] Budiman, Kris. 2004. Semiotika Visual. Penerbit Buku Baik, Yogyakarta

[3] Hoed, H Benny. 2014. Semiotik \& Dinamika Sosial Budaya. Komunitas Bambu, Jakarta.

[4] Kusrianto, Adi. 2007. Pengantar Desain Komunikasi Visual. Andi Offset, Yogyakarta.

[5] Swantoro, F. 2006. Dari Buku Ke Buku, Sambung Menyambung Menjadi Satu. KPG (Kepustakaan Populer Gramedia), Jakarta.

[6] Tinarbuko, Sumbo. 2008. Semiotika Komunikasi Visual. Jalasutra, Yogyakarta.

[7] Widiastuti, Tuti. 2014. Wacana Poskolonial dalam Desain Komunikasi Visual Kemasan Jamu Tradisional Indonesia. Jurnal Ilmu Komunikasi (JIK) UPNYK, Yogyakarta.

[8] Ratna, Kunta Nyoman. 2011. Metode Penelitian, Kajian Budaya, Ilmu sosial dan Humaniora pada Umumnya. Pustaka Pelajar, Jakarta. 
Batik merupakan salah satu kekayaan budaya Indonesia yang termasyhur dan telah diakui dunia melalui UNESCO sebagai warisan budaya dunia (Masterpiece of Oral and Intangible Heritage of Humanity) sejak tanggal 2 Oktober 2009, yang juga ditetapkan oleh pemerintah Indonesia sebagai Hari Batik Nasional. Istilah batik sendiri merupakan kata asli dari bahasa Jawa yaitu, Amba (menulis) dan titik.

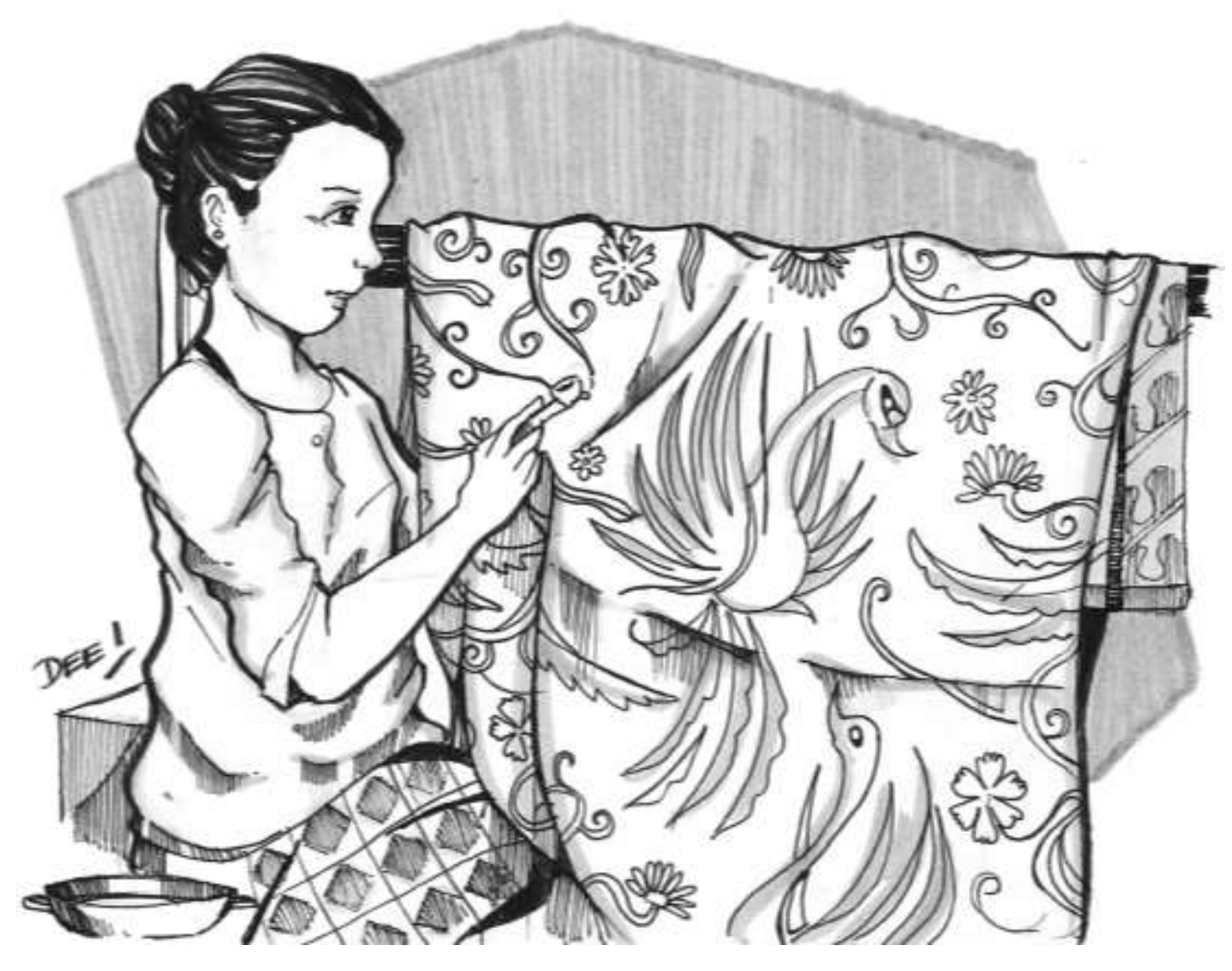

TRADISI BATIK NUSANTARA

ilustrasi oleh Dimas Krisna Aditya, Desember 2016 